МРНТИ 27.17

УДК 37.0:004 (075.8)

https://doi.org/10.51889/2020-2.1728-7901.15

\author{
Б. Мүсілімов ${ }^{1}$, 3.Е. Мұсабекова ${ }^{1}$ \\ ${ }^{1}$ Тараз мемлекеттік педагогикалық университет, Тараз қ., Қазақстан \\ МАТЕМАТИКА КУРСЫНДА АЛГОРИТМДЕУ ЖӘНЕ АРГУМЕНТАЦИЯЛАП \\ ОҚЫТУ ӘДІСТЕРІН ҮЙЛЕСТІРЕ ПАЙДАЛАНУ ТИІМДІЛІГІ ТУРАЛЫ
}

\begin{abstract}
Аң̧датпа
Ұсынылып отырған мақалада математика пәні бойынша білімді және біліктілікті сенімді бекітуде алгоритмдеу және аргументациялап оқыту әдістерін үйлестіре пайдалану тәсілі негізделген және оны тиімді түрде іске асыру мүмкіндігі, оның үлгісі көрсетілген. Бұл оқыту тәсілі студенттің өз бетінше тыңғылықты және жауапты жұмыс істеуін ұйымдастыруға, оның бойында ізденпаздықты, еңбекқорлықты қалыптастыруға, білім және біліктілігін сапалы жақсартып отыруға, тереңдетуге мүмкіндік береді. Сондықтан, қазіргі заманғы білім беру талаптарына сай математика пәні мұғалімі математиканы оқытудың сапасын жақсартудың негізгі технологияларын және жаңа әдіс-тәсілдерін білуі және тиімді қолданып отыруы керек болады.

Осы тиімді тәсілдегі тұжырымдалған идея кез келген бағыттар бойынша кәсіби деңгейі жоғары мамандар дайындауға оң септігін тигізе алады.

Түйін сөздер: иновациялық-педагогикалық және ақпараттық технологиялар, алгоритмдеп оқыту әдісі, аргументациялап оқыту әдісі, инженерлік техникалық мамандар, ақпараттық және коммуникациялық жасақтар.

\section{Аннотация \\ Б. Мусилимов ${ }^{\text {, 3.Е. Мусабекова }}{ }^{1}$ \\ ${ }^{1}$ Таразский государственный педагогический университет, г.Тараз, Казахстан \\ ОБ ЭФФЕКТИВНОМ СПОСОБЕ ИСПОЛЬЗОВАНИЯ СОЧЕТАНИЯ МЕТОДОВ АЛГОРИТМИЗАЦИИ И АРГУМЕНТИРОВАННОГО ОБУЧЕНИЯ В КУРСЕ МАТЕМАТИКИ}

В статье обоснован эффективный способ использования сочетания метода алгоритмизации и аргументированного обучения для надежного закрепления теоретических знаний и умений по математике, приведен конкретный пример с целью демонстрации его эффективности. Предложенный методический подход дает возможность студенту более эффективно организовываться и самостоятельно обучаться, успешно заниматься поиском, по своему усмотрению основательно изучать конкретный вопрос математики или кокретную тему. В этой связи современный преподаватель математики должен знать и владеть современными технологиями и методами обучения математике, уметь их эффективно применять на практике.

Основные методические идеи, предложенные авторами в приведенной статье могуть быть успешно использованы для улучшения общепрофессионального уровня студента любой специальности.

Ключевые слова: иновационно-педагогические и информационные технологии, алгоритмические методы обучения, аргументированный метод обучения, инженерно-технические специальности, информационные и коммуникационные средства.

\title{
Abstract \\ ON AN EFFECTIVE WAY TO USE THE COMBINED METHOD OF ALGORITHMIZATION AND REASONED LEARNING IN A MATHEMATICS COURSE \\ Musilimov B. ${ }^{1}$, Musabekova Z.E. ${ }^{1}$ \\ ${ }^{1}$ Taraz State Pedagogical University, Taraz s., Kazakhstan
}

The proposed article substantiates an effective way to use the combined method of algorithmization and reasoned learning for reliable consolidation of theoretical knowledge and skills in mathematics and provides a specific example to demonstrate its effectiveness. The proposed methodological approach allows the student to organize and study independently more effectively, successfully engage in search, and thoroughly study a specific question of mathematics or a specific topic at their own discretion. In this regard, a modern mathematics teacher should know and possess modern technologies and methods of teaching mathematics, be able to effectively apply them in practice.

The main methodological ideas proposed by the authors in this article can be successfully used to improve the General professional level of a student of any specialty.

Keywords: innovative pedagogical and information technologies, algorithmic teaching methods, reasoned teaching methods, engineering and technical specialties, information and communication teams. 
Жаңаша және жаңартылған мазмұнда білім беру және оқыту талаптарына сәйкес пән мұғалімдері білім беру шеберліктерін әрқашан жаңартып, жетілдіріп, жандандырып отырулары қажет болады, мейлінше тезірек қатып қалған стандарттардан арылулары тиіс. Сондықтан, қазіргі заманғы білім беру талаптарына сай математика пәні мұғалімі математиканы оқытудың сапасын жақсартудың негізгі технологияларын және жаңа әдіс-тәсілдерін білуі және оларды деркезінде меңгеруі, тиімді қолданып отыруы керек болады.

Өйткені, бүгінгі күнгі білім беру талабына сай жаңа үлгідегі инновациялық педагогикалық ғылым ерекшеліктерінің бірі - ол оқушылардың жеке өз бетінше білім алуын қолдай және бүгінгі күнгі білім деңгейін ескере отырып, жаңа білім алуына және оны дамытуға бағытталған жаңа оқыту технологияларын ұсыну болып табылады. Окушыларға жаңа ғасырда кәсіби, әлеуметтік және жеке табысқа жету үшін қажетті дағдыларды дамыту мүмкіндігін беретін жаңа білім бағдарламалары және тәсілдемелерін ұсынумен қатар, жаңаша, бүгінгі заман талабына сай келешек мамандықты таңдай алу мүмкіндігін де беру керек болады. Мұндай қасиетті оқушы бойында тиімді қалыптастыру оның өз оқулық қызметіне сыни тұрғыда қарай алуына және сыни тұрғыда логикалық ойлауын дұрыс қалыптастыру және дамыта, тиімді шешім қабылдай білуіне көп байланысты болмақшы.

Окушыларға берілетін білім мазмұнын қайта қарастыру маңыздылығы әлемнің жетекші елдерінің қатысуымен өтіп жүрген халықаралық деңгейде танылған алаңдарда да қарастырылып және талқыланып жүрген мәселе. Қазіргі кезеңдегі ұсынылып жатқан жаңа бағдарламалар пән мұғаліміне пәнаралық кіріктіруді іс жүзінде іске асыруға мүмкіндік беретіндей болуы тиіс, әсіресе, математика, физика, механика, информатика және жаратылыстану ғылымдары пәндері бойынша. Өйткені, бүгінгі заман талабына сай инженерлік және техникалық бағыттар бойынша кәсіби деңгейі жоғары мамандар дайындау мәселесі біздің елде өте өткір өзекті мәселеге айналып отыр.

Мысалы, оқу процесіндегі ақпараттық және коммуникациялық жасақтарды қолданудың өзі қолданбалы математиканың және информатиканың практикалық негізі болып есептеледі. Сондықтан, информатиканың негізгі міндеттерінің бірі пайдаланушыны (оқушыны, жалпы болашақ маманды) қолданыстағы, өмірдегі ғылыми-технологиялық жаңалықтармен байланыстыру болса, мұндай байланыстар үшін интеллектуалды оқыту жүйелері, оқытуға арналған программалық құралдар, автоматты оқыту жүйелері, электронды кітаптар, компьютерлік желі түрлері, жалпы ITтехнологиялардың жетістіктері, т.б. қолданылады. Осындай жаңа ақпараттық технологиялардың көмегімен әлеуметтік басқару жүйелерін өркендетуге, білім беру және ғылыммен айналысу сапасын, олардың ауқымдық деңгейлерін жақсартуға, жалпы дамытуға, кеңейтуге болады. Білім беру және ғылым салаларында жаңа технологияларды жүйелі пайдалану Елбасының «Қазақстан - 2050» Стратегиялық бағдарламасын, «Қазақстанның Үшінші жаңғыруы: жаһандық бәсекеге қабілеттілік» атты Жолдауын, «Болашаққа бағдар: рухани жаңғыру» бағдарламалық мақаласында, Ел Президенті Қ.Тоқаевтың 2019 жылғы Қазақстан халқына арнаған Жолдауында қойылған талаптарды ойдағыдай іске асырудың кілті және құралының бірі болып табылады [1].

Қазіргі кезеңде білім беру, оқыту жүйелеріндегі жаңа ақпараттық технологиялардың түрлері де сан алуан [2]. Мысалы, дидактикалық компьютерлік ойындар, арнаулы оқытушы программалар, қашықтықтан оқыту жүйесі, программалық тілдерді үйрену технологиялары, жаңа коммуникациялық технологиялар, офистік компьютерлік технологиялар, компьютерлік тесті құру және пайдалану технологиялары, электрондық оқулықтар, оқытушы мультимедия және гипермедия жүйелері және т.б. Осы аталған технологиялар қазіргі заманғы педагогикалық оқыту технологияларының негізгі құралына айналып отыр. Педагогикалық технология - оқушының даму шарттарының жиынын құрайтын, оқу-тәрбие процесінің міндеттері мен мазмұнын, түрлері мен әдістерін өзара концептуальды түрде байланысуын ұйымдастыратын әртүрлі пәндер мен әдістердің күрделі және ашық технологиялары болып саналады. Мысалы, қазіргі заманғы ақпараттық оқыту технологияларының ең тиімді әдістемелік негізі модульдік оқыту тәсілі болып отыр. Бүгінгі таңда осы модульдік оқыту тәсілін тиімді іске асырудың құралы болып табылатын оқулық элементті ақпараттық оқыту технологияларының - кез келген электрондық оқыту құралдарының басты әдістемелік (әсіресе қашықтықтан оқыту және білім беру технологияларының) негізі бола алады деп толық айтуға болады, сондықтан ол кез келген адамның, болашақ маманның, тіпті бүгінгі маманның да өз бетінше оқып білім алуына, білімін толықтыруына, жетілдіруіне, қажетті өз жеке білім траекториясын айқындауына мүмкіндін беретін педагогикалық программалық құралдарды дайындаудың да әдістемелік негізі бола алады [2].

Осындай қажетті оқулық элементті оқушыға/студентке пән мұғалімінің өзі ұсынуы керек. 
Олай болса оны пән мұғалімі оқушы/студент өз бетінше тиімді түрде жеке оқып-үйренуіне болатындай мазмұнда лайықтап дайындауына болады болады деген сөз. Сондықтан, оқулық элемент мазмұны көлемін және оның күрделілік деңгейін пән оқытушысы сыныптағы (академиялық топтағы) жеке оқушының (немесе студенттің) бүгінгі күнгі білімі деңгейіне және психологиялық ерекшелігіне сәйкес әртүрлі етіп деңгейлеп, саралап ұсына алады, яғни бұл сыныптағы әрбір жеке оқушының бүгінгі білім деңгейіне сәйкес оқулық элементтердің мазмұндарын және көлемдерін пән мұғалімінің өзінің таңдай отырып, қажетті деңгейде ұсынуына мүмкіндігі бар болады дегенді білдіреді. Осындай ұсынылатын оқулық элементтердің мазмұндарын таңдау және ондағы білім деңгейін бақылау барысында оқушы бойында жауапкершілік, қызығушылық, еңбекқорлық, өз жеке жетістігін сыни тұрғыда саналы бағалап отыру қасиеттерін қалыптастыру жақсы нәтижелерге жетуге он ықпал етеді. Мұндай қасиетті оқушы бойында тиімді қалыптастыру оның өз жеке оқулық қызметіне сыни тұрғыда қарай алуына және логикалық ойлауын дұрыс қалыптастыру және дамыта білуіне көп әер етеді.

Біздің ұсынып отырған оқыту тәсілі оқушының/студенттің өз бетінше тыңғылықты және жауапты жұмыс істеуін ұйымдастыруға, білім және біліктілігін сапалы жақсартып отыруға мүмкіндік береді. Біз оны мына бір сызықты алгебра курсынан алынған мысал негізінде негіздеп және үлгі ретінде көрсетейік.

Мысал. А матрицасына кері $A^{-1}$ матрицасын Гаусс әдісі қөмегімен табыңыз

$$
\mathrm{A}=\left(\begin{array}{lll}
1 & 2 & 5 \\
3 & 2 & 1 \\
1 & 1 & 1
\end{array}\right)
$$

Ұсынылған есепті шығаруда $A A^{-1}=A^{-1} A=E$ қасиетін пайдаланамыз, мұндағы Е - бірлік матрица. Бұл есепті шығаруда алгоритмдеу және аргументациялау (негіздеу) әдістерін үйлестіре пайдалану тәсілін ұсынамыз. Осы тәсілдің идеясы және оны пайдалану үлгісі [3-5] жұмысында келтірілген. Ұсынылған тәсілді пайдалану студентке (мысалы, мектепте оқушыға) бір уақытта бірнеше бағытта параллель тиімді жұмыс істеуге мүмкіндік береді, нәтижесінде студент теорияны да практианы да параллель қайталайды, меңгереді және сенімді бекітеді, оның білім және біліктілік деңгейі едеуір сапалы жақсарады, математикаға қызығушылығы арта түседі, еңбекқорлық және жауапты түрде жұмыс істей білу қасиеті оның бойында берік қалыптасады. Бұл тәсілді, мысалы, мектеп деңгейінде төменгі сыныптан бастап жүйелі түрде математиканы оқытуда және өз бетінше оқып-үйренуде пайдалану едеуір жақсы нәтижеге жеткізеді деп ойлаймыз. Ал ЖОО-ларда, әсіресе, инженерлік мамандық пәндерін өз бетінше оқып-үйренуде, жалпы кәсіби мамандық алуда, жақсы нәтиже беретіндігіне сенімдіміз.

Ұсынылып отырған тәсіл идеясын мына кесте түрінде көрсеткенді және түсіндіргенді жөн көріп отырмыз.

Кесте. Біліктілікті бекіту алгоритмі

\begin{tabular}{|c|c|c|c|}
\hline $\begin{array}{l}\text { Алгоритм } \\
\text { қ̧адамьв } \\
\text { нөмірі }\end{array}$ & $\begin{array}{c}\text { Алгоритм } \\
\text { құадамынының } \\
\text { қысссқаша } \\
\text { мазмұныl }\end{array}$ & $\begin{array}{c}\text { Алгоритмнің әр қадамын } \\
\text { аргументациялап } \\
\text { (негіздеп) отыру }\end{array}$ & $\begin{array}{c}\text { Алгоритмнің сәйкес } \\
\text { қадамдарының нақтыь } \\
\text { іске асырылуы }\end{array}$ \\
\hline 1 & 2 & 3 & 4 \\
\hline 1 & $\begin{array}{c}\text { «Кеңееитілген» } \\
\text { матрицань } \\
\text { жазу }\end{array}$ & $\begin{array}{c}\text { А матрицасының оң жавына бірлік } E \\
\text { матрицасын тіркеп жазу, явни }(A \mid E) \\
\text { түрінде жазу, мұндагы } A-\text { негізгі } \\
\text { матрица, Е - өлшемі (размері) A } \\
\text { матрицасымен бірдей болатын бірлік } \\
\text { матрица }\end{array}$ & $(A \mid E)=\left(\begin{array}{lll|lll}1 & 2 & 5 & 1 & 0 & 0 \\
3 & 2 & 1 & 0 & 1 & 0 \\
1 & 1 & 1 & 0 & 0 & 1\end{array}\right)$ \\
\hline 2 & $\begin{array}{l}\text { «Кеңейтілген» } \\
\text { матрицада А } \\
\text { матрицасын } \\
\text { сатыль түрге }\end{array}$ & $\begin{array}{c}(A \mid E)_{\text {матрицасының жатық }} \\
\text { жолдарына 1-щі және 2-ші типті } \\
\text { элементар түрлендірулер жүргізе }\end{array}$ & 2.1. $\left(\begin{array}{lll|lll}1 & 2 & 5 & 1 & 0 & 0 \\
3 & 2 & 1 & 0 & 1 & 0 \\
1 & 1 & 1 & 0 & 0 & 1\end{array}\right) \Rightarrow$ \\
\hline
\end{tabular}




\begin{tabular}{|c|c|c|c|}
\hline & келтіру & $\begin{array}{c}\text { (Гаусс әдісін пайдалана) отырып, } \\
\text { бірінші кез екте А матрицасын сатылы } \\
\text { түрге келтіреміз }\end{array}$ & 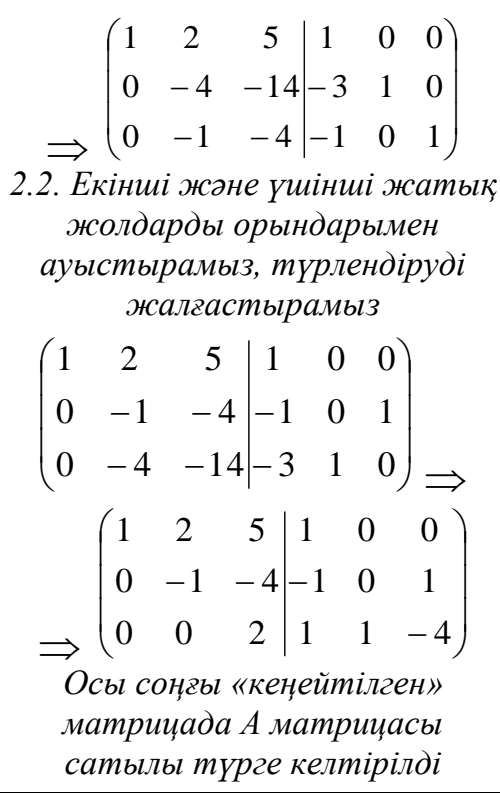 \\
\hline 3 & $\begin{array}{c}\text { Енді }(A \mid E) \\
\text { матрицасында } \\
\text { А-ны бірлік } \\
\text { матрицава } \\
\text { айналдыруымызыз } \\
\text { керек }\end{array}$ & $\begin{array}{c}\text { 1-, 2- және 3-ші типті элементар } \\
\text { түрлендірулер (Гаусс әдісі) көмегімен } \\
\text { соңды «кеңейтілген» матрищадавы A } \\
\text { сатылыль матрицасын бірлік матрицава } \\
\text { айналдыруга болады }\end{array}$ & \\
\hline 3.1 & & $\begin{array}{l}\text { TYрлендіруді соңвы жолдан бастаймыз. } \\
\text { Соңгы жолды 2-ге бөлеміз: }\end{array}$ & $\begin{array}{l}\left(\begin{array}{ccc|ccc}1 & 2 & 5 & 1 & 0 & 0 \\
0 & -1 & -4 & -1 & 0 & 1 \\
0 & 0 & 2 & 1 & 1 & -4\end{array}\right) \Rightarrow \\
\left(\begin{array}{ccc|ccc}1 & 2 & 5 & 1 & 0 & 0 \\
0 & -1 & -4 & -1 & 0 & 1 \\
0 & 0 & 1 & \frac{1}{2} & \frac{1}{2} & -2\end{array}\right)\end{array}$ \\
\hline 3.2 & & $\begin{array}{c}\text { Екінші жолдың элементтерін 4-ке көбе } \\
\text { итіп 3-ші жолдың сәйкес элементтерін } \\
\text { қосамыз, ал 1-ші жолдың элементтерін } \\
\text { (-5)-ке көбейтіп 3-ші жолдың сәйкес } \\
\text { элементтеріне қосамыз: }\end{array}$ & $\left(\begin{array}{ccc|ccc}1 & 2 & 0 & -\frac{3}{2} & -\frac{5}{20} & 10 \\
0 & -1 & 0 & 1 & 2 & -7 \\
0 & 0 & 1 & \frac{1}{2} & \frac{1}{2} & -2\end{array}\right)$ \\
\hline 3.3 & & $\begin{array}{c}\text { Соңвы матрицада екінші жолдың } \\
\text { барлық элементтерін (-1)-ге } \\
\text { көбейтеміз: }\end{array}$ & $\left(\begin{array}{ccc|ccc}1 & 2 & 0 & -\frac{3}{2} & -\frac{5}{20} & 10 \\
0 & 1 & 0 & -1 & -2 & 7 \\
0 & 0 & 1 & \frac{1}{2} & \frac{1}{2} & -2\end{array}\right)$ \\
\hline 3.4 & & $\begin{array}{c}\text { Соңды матрииада бірінші жолдың } \\
\text { барлық элементтерін 2-ге көбейтілген } \\
\text { екінші жолдың элементтерінен аламыз: }\end{array}$ & $\left(\begin{array}{ccc|ccc}1 & 0 & 0 & \frac{1}{2} & \frac{3}{2} & 4 \\
0 & 1 & 0 & -1 & -2 & 7 \\
0 & 0 & 1 & \frac{1}{2} & \frac{1}{2} & -2\end{array}\right)$ \\
\hline
\end{tabular}




\begin{tabular}{|c|c|c|c|c|c|c|}
\hline 3.5 & & $\begin{array}{c}\text { Соньмен, элементар түрлендірулер } \\
\qquad(A \mid E)_{\text {матрицасыл }}\left(E \mid A^{-1}\right) \\
\text { көмегімен } \\
\text { түріне келтіріліп тұр }\end{array}$ & & & & \\
\hline 3.6 & & $\begin{array}{c}\text { Түрлендірілген соңзы «кеңейтіл ген» } \\
\text { матрицаның сол жақ бөлігінде бірлік } \\
\text { матрица шывып тұр }\end{array}$ & & & & \\
\hline 3.7 & & $\begin{array}{c}\text { Ал түрлендірілген соңзвы «кеңейтілген» } \\
\text { матрицаның оң жақ бөлігінде } A^{-1} \text { кері } \\
\text { матрицасы алынды. } \\
A^{-1} \text { кері матрицасы мына түрде больли } \\
\text { тұр: }\end{array}$ & $A^{-1}=$ & $\begin{array}{l}\frac{1}{2} \\
-1 \\
\frac{1}{2}\end{array}$ & $\begin{array}{l}\frac{3}{2} \\
-2 \\
\frac{1}{2}\end{array}$ & $\begin{array}{r}4 \\
7 \\
-2\end{array}$ \\
\hline 4 & $\begin{array}{l}\text { Алььндан кері } \\
\text { матрицаны } \\
\text { жазып алу }\end{array}$ & Сонымен, есептің жауабын жазамыз & $A^{-1}=$ & $\begin{array}{l}0,5 \\
-1 \\
0,5\end{array}$ & $\begin{array}{l}1,5 \\
-2 \\
0,5\end{array}$ & $\left.\begin{array}{c}4 \\
7 \\
-2\end{array}\right)$ \\
\hline
\end{tabular}

Көріп отырғанымыздай, бұл тәсіл студенттер үшін үй тапсырмаларын және өзіндік жұмыста рды сапалы орындауда, теориялық материалдарды сенімді бекітуде өте пайдалы әдістемелік құрал болмақшы. Мысалы, бұл тәсілді мектептік математика курсын оқытуда 5-6 сыныптардан бастап тиімді пайдалануға болады деп есептейміз [6-8]. Өйткені, оқушы төменгі сыныптан бастап есеп шығару барысында есептеудің әр қадамын негіздеп (теорияны бекітіп) отыруға үйренеді, машықтанады, оның бойында тыңғылықты жұмыс істей білу қасиеті қалыптасады. Соған байланысты оқушы бойында ертеден бастап сыни тұрғыда ойлау қасиеті қалыптасады, ерте кезден тыңғылықты, жауапты еңбек ету дағдысы (еңбекқорлық) дамиды, математикаға деген қызығушылығы жылдан жылға арта түседі [9-12]. Өйткені, байқап отырғанымыздай, мұнда теория мен практика тікелей байланыстырылады, оқушының сыни тұрғыда ойлай алуы нәтижесінде теориялық білім саналы және сенімді бекітіледі, оның бойында ізденпаздық және еңбекқорлық, өз бетінше жауапты жұмыс істей білу қасиеті берік қалыптасады, оқулық әрекеттерді түрлендіріп және күшейтіп отыру қажеттіліктері туындайды, білімін тереңдету және кеңейтіп отыру мотивациясы алға шығады. Ұсынылып отырған тәсілді пән мұғалімі (оқытушысы) шығармашылық тұрғыда кез келген пәнді оқытуда және окушылардың (студенттердің) өз бетінше оқып-үйренуінде жүйелі түрде пайдаланатын болса, білім беруде жақсы нәтижеге жете алады деп ойлаймыз, оған сенімдіміз.

Пайдаланван ддебиеттер тізімі:

1 Полат Е.С., Бухаркина М.Ю., Моисеева М.В., Петров А.Е. Новые педагогические и информационные технологии в системе образования. - М.: АСАDEMA, 2007.

2 Тренерге арналган нұсқаульқ.- «Назарбаев Зияткерлік мектептері» ДББҰ, 2015.

3 Мүсілімов Б. Сызықты алгебра элементтері. -Тараз, 2015.

4 Математика әлемі. Математикадан пәндік эничиклопедия. - Алматьл, 2011.

5 Мүсілімов Б. Матрица және оператор. - Тараз, 2017.

6 Дуйсембаева Э.К., Ильясова Р.А. Использование информационно - коммуникационных технологий в процессе обучения математике// Вестник КазНПУ. Серия «Физико-математические науки» - 2018. - №3(63). - C.347-351

7 Калинченко А.В. Методика преподавания начального курса математики. Учебное пособие. М.:Академия, 2017.

8 Активные методь обучения на уроках математики в начальной школе/ сост.: Кушнир М.П., Мендыгалиева М., Петрик Е.П. Астана: АОО «Назарбаев Интеллектуальные иколь», 2017.

9 Белошистая А.В. Методика обучения математике в начальной школе: курс лекций.- М.:Владос, 2016.

10 Сатыбалдиев О.С., Нурбавлиев О.К. Боламақ математика мұвалімдерінің кәсіби даярлықтарының, негізгі көрсеткіштері// ҚазҰПУ Хабаршы. «Физика-математика вылымдары» сериясы - 2017. - №3(59). - 125-132 б.

11 Алпысов А.К. Методика преподавания математики. Учебное пособие. Павлодар. 2012.

12 Далингер, В.А. Методика обучения математике в начальной школе. Учебное пособие для академического бакалавриата / В.А. Далингер, Л.П. Борисова. - Москва: Наука, 2016. 


\section{References:}

1 Polat E.S., Buharkina M.Ju., Moiseeva M.V., Petrov A.E. (2007) .Novye pedagogicheskie i informacionnye tehnologii $v$ sisteme obrazovanija [New pedagogical and information technologies in the education system]. M.: ACADEMA. (In Russian)

2 Trenerge arnalgan nuskaulyk.(2015) [Trainer's Guide]. «Nazarbaev Zijatkerlik mektepteri» DBBҰ (In Kazakh)

3 Mysilimov B. (2015).Syzykty algebra jelementteri [Elements of linear algebra]. Taraz (In Kazakh)

4 Matematika alemi (2011) [The world of mathematics]. Matematikadan pandik jenciklopedija. Almaty. (In Kazakh)

5 Mysilimov B. (2017) Matrica zhane operator [Matrix and operator]. Taraz. (In Kazakh)

6 Dujsembaeva Je.K., Il'jasova R.A. (2018) Ispol'zovanie informacionno - kommunikacionnyh tehnologij $v$ processe obuchenija matematike [The use of information and communication technologies in the process of teaching mathematics]. Vestnik KazNPU. Serija «Fiziko-matematicheskie nauki». №3(63). 347-351. (In Russian)

7 Kalinchenko A.V.(2017) Metodika prepodavanija nachal'nogo kursa matematiki. Uchebnoe posobie.[ Methods of teaching an elementary course in mathematics. Tutorial]. M.:Akademija. (In Russian)

8 Aktivnye metody obuchenija na urokah matematiki v nachal'noj shkole (2017) [Active teaching methods in math lessons in elementary school]. sost.: Kushnir M.P., Mendygalieva M., Petrik E.P. Astana: AOO «Nazarbaev Intellektual'nye shkoly» (In Russian)

9 Beloshistaja A.V. (2016) Metodika obuchenija matematike v nachal'noj shkole: kurs lekci j[Methods of teaching mathematics in elementary school: a course of lectures]. M.:Vlados. (In Russian)

10 Satybaldiev O.S., Nurbavliev O.K. (2017) Bolashak matematika mugalimderinin kasibi dajarlyktarynyn negizgi korsetkishteri [Basic indicators of professional training of future mathematics teachers]. KazUPU Habarshy. «Fizikamatematika gylymdary» serijasy №3(59). 125-132.

11 Alpysov A.K. (2012) Metodika prepodavanija matematiki. Uchebnoe posobie [Methods of teaching mathematics]. Pavlodar. (In Russian)

12 Dalinger, V.A. (2016) Metodika obuchenija matematike $v$ nachal'noj shkole. Uchebnoe posobie dlja akademicheskogo bakalavriata [Methods of teaching mathematics in primary school Academic Baccalaureate Study Guide]. V.A. Dalinger, L.P. Borisova. - Moskva: Nauka. (In Russian) 